\title{
ФОРМУВАННЯ ПРОФЕСІЙНОЇ КОМУНІКАТИВНОЇ КОМПЕТЕНТНОСТІ У СТУДЕНТІВ-МЕДИКІВ 4-6-Х КУРСІВ ФАКУЛЬТЕТУ ПІДГОТОВКИ ІНОЗЕМНИХ ГРОМАДЯН ПРИ ВИВЧЕННІ ДИСЦИПЛІНИ «ПЕДІАТРІЯ»
}

ДВНЗ «Івано-Франківський національний медичний університет»

Резюме. У статті наведені дані щодо основного змістового поняття професійної комунікативної компетентності, формування якої у студентів-іноземців, що навчаються у вищих медичних закладах, $\epsilon$ непростим завданням. Особлива роль при вивченні дисципліни «Педіатрія» відводиться комунікативним здібностям студента у спілкуванні з хворими дітьми та їх батьками. Автором окреслено основні складові професійної кому-

Вступ. В інформаційно-перенасиченому, технологічно оснащеному суспільстві особливої ваги набуває безпосередня комунікація між людьми, починаючи з учнівської та студентської лави, і закінчуючи виконанням особою професійних та службових обов'язків.

Комунікативна функція мови є важливим інструментом гуманізації освітньої парадигми загалом, що сприяє підвищенню ефективності навчально-освітнього процесу, комплексному вирішенню проблем духовно-морального становлення особистості особи, що навчається [1-3].

Водночас на сучасному етапі фахівець, незалежно від галузі та сфери діяльності, повинен вміти швидко сприймати, аналізувати та розуміти будь-яку інформацію, що надходить зусібіч $[5,6]$.

Керуючи системою мовленнєвих комунікацій у межах своєї компетентності, він здатний приймати необхідне рішення, вибудувати алгоритм необхідних дій та забезпечити правильний результат своєї праці.

Отже, знання, як правильно використовувати мовні засоби для засвоєння, обробки та аналізу визначеного Навчальним планом та Робочою програмою обсягу інформації, необхідні студенту будь-якої спеціальності [1-4].

Аналіз наукової літератури за останні роки [1-4, $5,6]$ дозволив виокремити низку протиріч у структурі професійної мовленнєвої компетентності та комунікації в умовах вищого навчального закладу загалом:

1. Існує різниця між соціальним замовленням різних держав на випускника вишу, який здатний успішно діяти в полінауковому комунікативному просторі, та недостатньою увагою, що приділяється з боку освітянської галузі становленню комунікативних здібностей і компетентності фахівця, незалежно від профілю та спеціалізації.

2. 3 одного боку, зростає потреба студента бути успішним прогресивним індивідуумом, 3 іншого, - його розвиток гальмується відсутністю комплексу педагогічних зусиль, спрямованих на ефективність такої підготовки.

3. Постійно відмічається розрив між потребою педагогічної практики у виявленні факторів успішності студента та розробкою теоретичних (C) I.C. Лембрик, 2016 254 нікативної компетентності, проблеми та шляхи іiі набуття з огляду на специфіку роботи 3 контингентом іноземних студентів. Підкреслено роль новітніх технологій у методології навчально-освітньо-виховного процесу у вищому медичному закладі.

Ключові слова: педіатрія, комунікація, компетентність, студент-іноземець.

основ використання комунікативної компетентності у процесі навчально-освітньої діяльності $[1,3]$.

У нашій статті ми хочемо зупинитися на формуванні професійної мовленнєвої компетентності лікаря на прикладі навчання студентів-медиків факультету підготовки іноземних громадян.

Мета дослідження. Визначити основні шляхи формування професійної мовленнєвої компетентності у студентів-медиків факультету підготовки іноземних громадян.

Матеріал і методи. Проведено аналіз джерел літератури за останні 10 років, присвячених проблемі, що висвітлюється.

Результати дослідження та їх обговорення. Професійна мовленнєва компетентність (лат. competens - належний, відповідний) набувається у сфері професійної діяльності комунікантів, та може проходити в усній, письмовій формах та он-лайн, за офіційних чи неофіційних обставин, залежно від мети комунікації. Вона $\epsilon$, до речі, базовою складовою поняття «спілкування», широко прийнятого в соціальній психології [1-4].

Форми, умови, аспекти професійної діяльності визначають види та особливості формування комунікативної компетентності [3, 4]. Наприклад, від умов спілкування безпосередньо залежить лексично-семантичний склад і стиль мовлення (розмовний чи діловий), а певні мовнокомунікативні вміння визначаються професією чи умовами праці індивіда: лікарня, школа чи вищий навчальний заклад [1-5].

Відмітимо, що майбутній лікар уже 3 перших курсів навчання в медичному виші опановує ази ділового мовлення, які йому однозначно знадобляться в подальшому житті [1-4]. Адже ділове мовлення є невід'ємною складовою професійної компетентності вже на етапі прийняття на роботу [1-3]. Тут у нагоді стануть: вміння написати резюме, оформити службову чи ділову документацію, виступати з доповіддю чи рапортом, укладати угоди, спілкуватися по телефону, писати електронні листи, брати участь у співбесіді тощо.

I тут постає головна проблема студентаіноземця, який приїздить в Україну з метою здобути вищу медичну освіту. 
По-перше, одразу виникає низка бар'єрів, таких, як мовний та психологічний, у спілкуванні не лише $з$ викладачем, але й 3 хворою дитиною та/або їі родичами.

По-друге, проявляються індивідуальнопсихологічні особливості особи іноземця, оскільки на його спілкування накладають відбиток расова, етнічна, релігійна та гендерна приналежність.

Наприклад, студент із країн Південного Сходу та Східної Азії нерідко відмовляється спілкуватися та обстежувати дівчинку-підлітка, яка і одягнута нескромно, на його погляд, і поводить себе зухвало, оголюючи тіло для обстеження (перкусії та аускультації і т.д.). Студенти з Індії та африканських країн часто бояться насильства, ксенофобських настроїв з боку інших студентів, хворих та їх батьків у палаті під час фізикального обстеження тощо. Нерідко мають місце сварки та суперечності в межах різних культур, як от між вихідцями із Туркменістану, Казахстану та африканських країн тощо.

По-трете, таких студентів погано інформують про основи законодавства нашої країни у сфері освіти, їх права і обов'язки як студента медичного вишу згідно з Положеннями чи статутами відповідного навчального закладу, Кодексом честі медичного працівника.

3 огляду на великий наплив мігрантів, носіїв чужої культури в європейські країни, такі роз'яснення слід давати уже тепер, щоб уникнути в майбутньому непорозумінь, а то і відвертого саботажу іноземцями законодавчо закріплених умов навчання, елементарних норм поведінки.

I, нарешті, самі працівники медичних закладів, хворі діти, їх батьки та родичі самі виявляють низький рівень загальної культури та упередженість, бачачи перед собою іноземця. Дається взнаки дуже погане володіння іноземними мовами, бідний словниковий запас, страх перед іноземцями та представниками інших рас і національностей.

Як бачимо, існує пласт проблем, які пов'язані 3 певною специфікою викладання клінічних дисциплін студентам факультету підготовки іноземних громадян, а формування у них професійної мовленнєвої компетентності є нагально необхідним.

Зазначимо, що загалом професійна мовленнєва компетентність грунтується на гуманітарній культурі, глибоких та грунтовних професійних знаннях (навчання специфічної медичної термінології, особливостей спілкування $з$ дітьми та їх родичами, правил поведінки в аудиторії та біля ліжка хворого).

Людина, яка володіє в достатньому обсязі професійними комунікативними навичками, вміє зорієнтуватися в навколишньому світі, має певні відчуття, у тому числі внутрішнього психолога, формує в собі навички і вміння правильного спілкування. Тобто, у першу чергу, йдеться про комунікативну компетенцію [1-3].

Комунікативна компетенція, як відомо, це сукупність знань про спілкування загалом, незалежно від умов та осіб комунікантів, а також уміння ефективно застосовувати ці знання в кон- кретному спілкуванні (зі зміною ролей адресанта і адресата [1-4].

Комунікативна компетенція передбачає володіння мовленнєвими уміннями й навичками, необхідними для спілкування, сукупність знань про норми та правила ведення природної комунікації. Важливими складниками комунікативної компетенції є мовна та мовленнєва компетенція.

Мовна компетенція - знання учасниками комунікації норм і правил сучасної літературної мови 3 подальшим їх вмілим застосуванням на практиці [4-7].

Мовна компетенція складається 3 лексичної, граматичної, семантичної, фонологічної, орфографічної, орфоепічної та пунктуаційної компетенцій.

Мовленнєва компетенція - загальне коло питань мовленнєвої діяльності, що передбачає наявність відповідних знань, умінь, досвіду. Ця компетентність $є$ конкретною мовленнєвою обізнаністю індивіда, специфічною за родом діяльності $[1,3,5,7]$.

Слід відмітити, що одна без іншої апріорі не буває, оскільки мовленнєва компетенція у процесі спілкування спирається на мовну. Без багатого запасу слів та багажу прочитаного студенту буває надзвичайно тяжко висловитися, вести діалог, вступати у дискусію, відповідати на запитання викладача, вловлювати основну думку логічно побудованого ситуаційного завдання чи тесту $[1,3,5,7]$.

У цьому випадку мовна компетентність включає систему певних навичок та вмінь, згаданих вище (уміння вести діалог, дискусію, брати участь у консиліумі, обговоренні хворого після нічного чергування, користуватися професійним словником у формулюванні діагнозу, віднайти шляхи оптимізації діагностики, лікування та профілактики) [1-3].

Мовленнєва компетентність визначає загальне коло комунікативних умінь та навичок, що детермінує розумовий розвиток індивіда, забезпечує успішне засвоєння ним основ наук. Ї̈̈ завдання полягає в тому, щоб збагачувати словник фахівця, сформувати в нього вміння точно й правильно висловлювати свої думки ясно, просто, послідовно, логічно, виразно й переконливо, зрозуміло як для нього, так і для інших [1-3].

Це тим паче актуально у викладанні іноземцям основ педіатрії, адже нерідко стикаємося на практиці 3 односкладовими відповідями на запитання, початком дискусії з кінця, відвертим нерозумінням логічної конструкції речення, відсутністю знань про те, як працювати з дітьми і підлітками тощо.

3 іншого боку, ми свідомі того, що не всі викладачі самі на високому професійному рівні володіють бодай англійською мовою, що і породжує подібний когнітивний та семантичний дисонанс.

Яким чином формується професійна мовленнєва компетентність? На думку дослідників [3, 6, 7] iii набуття передбачає низку пунктів:

- наявність глибоких професійних знань та підготовки $з$ попередніх курсів; 
- володіння понятійно-категоріальним апаратом та певною специфічною термінологією 3 окремо взятої дисципліни (у нашому випадку, педіатріі);

- досконале володіння мовою, обраною для спілкування;

- вміле застосування різних мовних стилів, жанрів, відповідно до місця, часу, обставин, статусно-рольових характеристик партнера по спілкуванню;

- вміння працювати з різними типами друкованих і електронних носіїв інформації;

- здатність виокремити 3 текстів ключову думку, позицію;

- орієнтацію в потоках різнопланової і різнотипної інформації, що надходить із різних джерел та інтернет-ресурсів, і не завжди є вивіреною та захищеною авторським правом;

- спроможність віднаходити, сприймати, аналізувати та використовувати інформацію цілеспрямованого та профільного спрямування;

- опанування інтерактивними та цифровими технологіями, характерними ознаками яких $\epsilon$ активне діалогове спілкування між кількома комунікаторами, миттєва реакція на інформацію;

- володіння основами риторичних знань та вмінь;

- уміння дуже швидко оцінювати комунікативну ситуацію, і на високому професійному рівні спланувати подальшу стратегію і подальші дії.

Загалом, комунікативна компетентність у вищому медичному закладі розглядається як професійно значуща домінанта успішності навчально-виховної діяльності, і є, на наш погляд, професійно пріоритетною якістю особистості, що характеризується мірою залучення суб' єкта в комунікативну діяльність [1-3]. При цьому завжди оцінюватиметься якість, а не кількість трансформацій особистісних якостей студента, таких, як інтерес, активність та самостійність [1-4, 5].

Отже, професійна мовнокомунікативна компетенція особистості є маркером сформованості системи професійних знань, комунікативних навичок та вмінь, ціннісних орієнтирів, загальної гуманітарної культури, інтегральних показників культури мовлення студента або особи, яка навчається чи дотична до навчального процесу, необхідних для виконання нею надалі своїх професійних обов'язків.

На думку низки вчених, комунікативна компетентність студента визначається усього лише трьома компонентами: когнітивним (наявність певного кругозору та професійно-зорієнтованого словникового запасу (тезауруса)); операційнодіяльнісним, що $є$ усвідомленим володінням мовними засобами експліцирування змістових співвідношень між елементами та поняттями тезауруса; мотиваційно-ціннісним - включає у себе сукупність якостей особистості, що сприяють успішному навчанню та взаємодії усіх учасників навчально-освітнього процесу, та, врешті, досяг- ненню його кінцевої мети - підготовки високоерудованого та кваліфікованого фахівця [1-7].

Педагогічна складова застосування комунікативної компетентності, що сприяє кращій успішності студента, включає розвиток позитивної мотивації до вивчення дисципліни та установки на формування професійної мовленнєвої компетентності; збагачення змісту гуманітарних тренінгів на підготовчому і першому курсах комунікативною спрямованістю; реалізація в навчально-освітньому процесі комунікативних технологій, доступних в умовах медичного вишу $[2,3,5]$. Окремо слід спинитися на тих компонентах навчальної діяльності (мотиваційно-цільовому, операційно-процесуальному, контрольно-оцінковому), які оптимізують комунікативну складову професійної діяльності у процесі навчання $[2,3,5,6]$.

Для формування професійної мовленнєвої компетентності важливу роль повинна відігравати сучасна модернізована, оптимізована система освіти, що активно використовує широкий арсенал різних педагогічних методик та інноваційних технологій (цифрових, інтерактивних). Йдеться про комп’ютерні класи, зали відеоконференцій, використання планшетів, смарт-фонів та інших гаджетів у навчально-освітньому процесі [1-3].

Ми переконані, що широке впровадження в навчально-освітній процес цифрових технологій покликане стимулювати зацікавленість студентаіноземця в поглибленні не лише набутих навичок та вмінь, але й формування звички правильно розмовляти, вести дискусію, підтримувати бесіду та ін.

На наш погляд, у вищому навчальному закладі таку проблему можна вирішити шляхом:

- проведення сітки вебінарів, майстер-класів, он-лайн тренінгів та курсів зростання професійної мовленнєвої компетентності та ораторської майстерності з відповідним залученням лінгвістів, психологів та логопедів;

- укладання професійного глосарія 3 тлумаченням окремих медичних термінів та викладенням його в он-лайн варіанті на сторінці кафедри;

- вивчення основ етики та деонтології в педіатрії за допомогою навчальних фільмів або мультфільмів;

- активніше залучення студентів-іноземців до культурно-просвітницької роботи в позааудиторний час із вивченням відповідної кількості віршів, скоромовок, загадок та ребусів як рідною, так і українською мовами;

- проведення низки інтелектуальних квестів та брейн-рингів між студентами факультету підготовки іноземних громадян з актуальних питань педіатрії;

- стимулювання практичної діяльності та активного ужитку мовного арсеналу таких студентів у рамках нічних та денних чергувань по стаціонару;

- заохочення відвідин студентами-іноземцями наукового гуртка 3 подальшим написанням наукових доповідей, рапортів та/або коротких 
повідомлень, присвячених актуальним питанням педіатрії та медицини загалом.

Щодо рис комунікативної компетентності, яка безумовно, знадобиться студенту-іноземцю в спілкуванні з хворими, батьками та їх оточенням, можемо виокремити: комунікабельність і багатий професійний тезаурус, відкритість, щирість, приязнь, адекватність, обережність, тактовність, маломовність на тлі стриманої міміки та рухової активності (надміру емоційна реакція, підвищена рухова активність властиві, насамперед, африканцям), ерудованість та компетентність.

\section{Висновки}

1. Комунікативна компетентність та ії основні складові - мовна та мовленнєва компетентності, поруч з ефективною практичною діяльністю, $€$ запорукою успішності навчання та досягнення його основної мети - підготовки висококваліфікованого фахівця, здатного думати і приймати нестандартні та, головне, швидкі рішення.

2. При формуванні засад комунікативної компетентності у студента-іноземця слід враховувати його соціально-культурні, релігійні, расові та гендерні відмінності від наших студентів.

3. Формування комунікативної компетентності із професійною спрямованістю не видається можливим без широкого використання арсеналу цифрових технологій (вебінарів, он-лайн трансляцій фільмів та тренінгів).

Перспективи подальших досліджень. Активне впровадження цифрових технологій у на- вчально-освітній та виховний процес на кафедрі педіатрії.

\section{Література}

1. Бацевич Ф.С. Онови комунікативної лінгвістики: підручник / Ф.С. Бацевич. - К.: Академія, 2004. - 344 с.

2. Галицька М.М. Складові комунікативної компетентності студентів вищих навчальних закладів / М.М. Галицька // Освітологічний дискурс. - 2015. № 2 (10). - C. 39-48.

3. Глигало Ю.В. Соціально-перцептивна компетентність майбутніх фахівців соціальної сфери в процесі професійної підготовки [Електронний ресурс] / Ю.В. Глигало // Теорія та методика управління освітою. - 2010. № 5.- Режим доступу : http://tme.umo.edu.ua/ docs/5/11glispt.pdf.

4. Долгова В.И. Управление инновационными процессами в образовании: сущность, закономерности и тенденции / В.И. Долгова, В.А. Ткаченко // Наука и бизнес: пути развития. -2012 . - № 7. - С. 17-22.

5. Долгова В.И. Понятие коммуникативной компетентности в психолого-педагогических исследованиях / В.И. Долгова, Е.В. Мельник, Н. Карахан // Концепт. 2015. - Триангуляция результатов количественного и качественного анализа развития психических процессов коллективным субъектом профессор-доцентстудент. - 2015. - ART 95523. - URL: http: //ekoncept.ru /2015/95523.htm.

6. Силкина Н.В. Развитие гуманитарной культуры студента в образовательном пространстве вуза. Образовательная среда как фактор качественной профессиональной подготовки: материалы Всерос. науч.-практ. конф. // СГУПС, НТИ МГУДТ. - Новосибирск: Изд-во СГУПСа, 2011. - 522c. - С. 163-167, С. 262-267.

7. Шадриков В.Д. Новая модель специалиста: инновационная подготовка и компетентностный подход / В.Д. Шадриков // Выс. образование. - 2005. - № 6. C. 26-29.

\section{ФОРМИРОВАНИЕ ПРОФЕССИОНАЛЬНОЙ ЯЗЫКОВОЙ КОМПЕТЕНТНОСТИ У СТУДЕНТОВ-МЕДИКОВ 4-6-Х КУРСОВ ФАКУЛЬТЕТА ПОДГОТОВКИ ИНОСТРАННЫХ ГРАЖДАН ПРИ ИЗУЧЕНИИ ДИСЦИПЛИНЫ «ПЕДИАТРИЯ»}

\section{И.С. Лембрик}

Резюме. В статье представлены данные по поводу основного смыслового понятия профессиональной коммуникативной компетентности, формирование которой у студентов-иностранцев, учащихся в высших медицинских учреждениях, является непростой задачей. Особенная роль при изучении дисциплины «Педиатрия» отведена коммуникативным способностям студента-иностранца в общении с больными детьми, их родителями. Автором определены основные составляющие профессиональной коммуникативной компетентности, проблемы и пути ее получения с учетом специфики роботы с контингентом иностранных студентов. Подчеркнута роль новейших технологий в методологии образовательно-учебно-воспитательного процесса в высшем медицинском учреждении.

Ключевые слова: педиатрия, коммуникация, компетентность, студент-иностранец.

\section{FORMATION OF PROFESSIONAL COMMUNICATIVE COMPETENCE IN FOREIGN STUDENTS $4^{\text {TH }}-6^{\text {TH }}$ YEARS IN MEDICINE DURING STUDYING THE DISCIPLINE "PEDIATRICS"}

\section{I.S. Lembryk}

Abstract. The article presents data on the basic semantic concept of professional communicative competence formation of which in foreign students enrolled in higher medical institutions is a challenge. A special role in the study of the subject "Pediatrics" is given to student communication skills in dealing with sick children and their parents. The author outlines the main components of professional communicative competence, problems and the ways of its gaining given the specificity of the contingent of foreign students. The role of new technologies in the methodology of teaching and educational process in higher medical institution is emphasized.

Key words: pediatrics, communication, competence, foreign student.

HSEI "National Medical University" (Ivano-Frankivsk)

Рецензент - проф. О.К. Колоскова

(C) I.C. Лембрик, 2016
Buk. Med. Herald. - 2016. - Vol. 20, № 1 (77). - P. 254-257 